\title{
IN MEMORIAM JAN HERMAN VAN ROIJEN (1905-1991)
}

The death of Herman van Roijen meant not only the disappearance of a very important personality from Dutch public life but also of a man of unusual qualities who made a special contribution to international relations of our age. His career was crowned by the outstanding ambassadorships in Canada, the United States and the United Kingdom. In all of these countries Herman gained not only personal friends, but also forged deep links, profound mutual understanding between governments of his country and the host state. He did much more, he contributed to the development of friendship between peoples. For he was indeed an unusual man.

He prepared his doctoral thesis at Utrecht University in 1929 on 'The Legal Status of International Recognition of Newly Created States and Governments'. He could hardly guess that twenty years later he would be heading his country's delegation preparing a round table conference with Indonesia, a country which, formerly under control of the Netherlands, gained independence as one of the newly born states of the world community. Thus life offered him very many surprises but he lived up to them due to his capacity of mind and the special features of his character. Up to his last fatal illness he reflected his unusual personality, the eagerness to know and of absorbing as much knowledge as possible. Not insisting to convince people to his views he much rather helped them to find their own way. Hence it was his own courtesy -more I would say kindness- which attracted so many to seek his company. Always quiet, rarely tense, he continued with his attempts to understand why governments act so and not otherwise. He did not seek publicity. Every meeting with him brought something new and interesting; whatever subject one touched upon he would leave you to thoughts you never engaged in or pursued to the very end.

Well-read, commanding excellent information on all issues of international politics, he was able to direct conversation and influence people through his straightforwardness and through his understanding of the position of his own government and the others to which he was accredited. Small wonder that he was a master in gaining friends.

In his own quiet way he was one of the outstanding figures of his generation. Strangely enough he achieved this status because he did not follow two pieces of advice given on the subject. One came from the Marquis de Noailles who claimed: "We are not here to resolve problems [...] we should be satisfied by carefully following those which are not soluble, the others will be solved by themselves". Nor did he follow the advice of that great teacher of diplomacy, Harold Nicolson: "There is nothing more damaging to precision in international relations than friendliness between contracting parties. Diplomacy, if it is ever to be effected, should be a disagreable business". 
Herman van Roijen practised the opposite, trying to make friends with those whose views he shared and those with whom he disagreed. His recipe worked wonders for he has thus been able to create bonds which paved the way to ever closer relations between states and lasted much longer than any formal relation will do. Thus one may have disagreed with him on very essential issues but while one continued to talk these differences seemed to melt away and finally they seemed to disappear, at least in part. This art in gaining friends had a political dimension for in doing so he also created new potential allies to the cause he defended and the interests he pleaded for. It is a small wonder that he felt at home at Capitol Hill and in the Department of State, in the House of Commons and in Whitehall. The Netherlands could not have had a better analyst and advocate of its causes than him. One president succeeded one another and so did Prime Ministers, but Herman remained watchful and relations between the countries to which he was accredited were not to suffer, they continually improved until they became excellent. While serving bilateral diplomacy he was also a strong supporter of the United Nations and it is there where he had to deal with certain issues entrusted to him by his government. He was also one of those who deeply regretted the division of the world in which he was working: the Iron Curtain, which divided Europe, and his commitment to Radio Free Europe and to the cause of the liberation of Eastern Europe which was to come. How fortunate that he lived to see this event occur. Finally, when the time of his retirement came, he decided not to remain idle or unemployed. He was chosen to head the Carnegie Stichting thus to preside the Administrative Council of the Hague Academy of International Law as well as the International Court of Justice. It is a strange historical coincidence that a quarter of a century earlier, in his capacity of Minister of Foreign Affairs, he took part in the inaugural sitting of the International Court of Justice held on August 18, 1946. Today, forty-five years later, it may be worth recalling some parts of the statement he made on that occassion:

You have come, gentlemen, to a country partly devastated the by war, to a city of which whole sections have been bombarded, but you find yourself in a building which has survived almost undamaged. Would it be too far-fetched to regard this fortunate survival as symbolic of the internal value of law to which this Palace has been dedicated?

In his wisdom he admitted: "There is no doubt in the present shaken condition of the world, that the administration of justice is very important, but it also extremely difficult". He went beyond his usual courtesy speeches made on such occasions. He contested the view of Montesquieu that "Judges are but the mouthpiece which recites the law - inanimate beings who cannot moderate either its force or its vigour". He claimed that this view was "very far from having met with universal acceptance" and suggested that this conception of the judges' function is still less applicable in international law. 
the exercise of their function demands the possession of high qualities of mind and character by judges; for like all of us, they are linked by every fibre of their being to their national conceptions and aspirations of their own country. Their task requires a calm atmosphere, it would hindered by the commotions of political life.

He was proud, he expressed pride in the Court having its seat in The Hague:

As in 1920, so also upon the creation of the new Court, it was rightly recognised that the World Tribunal should have its seat in a place where the clamours of political life could not disturb the quiet atmosphere indispensable to the administration of justice. It is a source of great regret to us, Gentlemen, that this city and country cannot offer you all that it was possible to provide before the War, at all events not in the immediate future. I venture nevertheless to hope that you will find here an environment lending itself to the succesful accomplishment of your task. So far as the Queen's Government is concerned, we can assure you that we shall do everything in our power to faciltate your work.

Today his prophecy can be said to have been fulfilled. The Government of the Netherlands not only provided the facilities of the building which was inaugurated in 1946, but also a building for judges' offices. It was constructed while Herman van Roijen was President of the Carnegie Stichting. With pride and satisfation he maintained cordial relations with the Court. Moreover, as President of the Administrative Council, he paid particular attention to the work of the Hague Academy of International Law. It then celebrated, in 1972, its 50th anniversary. The Academy has since been able to further expand its teachings, reaching into the Third World and to countries of Eastern Europe. It was then, in that work and those capacities that I came in closer contact with Herman van Roijen. He and his faithful companion, Anne, were excellent hosts to many professors coming from all parts of the world to The Hague to teach. I highly valued those meetings.

A master in conversation and reflection, he could look back at his life as one of great achievement, of having contributed to the improvement of his own country with the whole western world and beyond it. For Herman van Roijen was really a great humanist who displayed this capacity in exercising functions in which this quality is not very much appreciated and is not coming to the forefront, but due to his uniqueness he has been able to combine the formality of diplomatic life with deep humanity in the exercise of international politics and thus was able to till grounds from diplomacy to law, from law to teaching, retaining interest in all of them and maintaining contact with all the branches of these areas of human activity. In mourning his demise we think of him with great emotion but also consider ourselves fortunate for having known him and having shared with him the great beauties of life and the ambitions to make this world a better place for nations and men.

* Manfred Lachs is Judge at the International Court of Justice. 